\title{
HUBUNGAN KEBIASAAN SENAM, ASUPAN KALSIUM DAN VITAMIN C DENGAN DENSITAS MASSA TULANG
}

\author{
The Relationship between Doing Gymnastics Regularly, Intake of Calcium and \\ Vitamin C with Bone Mass Density
}

\author{
Ginta Siahaan, Erlina Nasution, Urbanus Sihotang \\ Politeknik Kesehatan, Jurusan Gizi, Kemenkes Medan \\ E-mail: ginzsiahaan@gmail.com
}

\begin{abstract}
Osteoporosis in women starting at the age of 30 years and increased significantly at the age of 50 years, or around the age of menopause and prevalence of osteoporosis is 80 percent occurred in women. Prevention can be done with doing exercise and giving attention to a high dietary intake of calcium and vitamin $\mathrm{C}$. The purpose of this study was to determine the gymnastic habits, intake of calcium and Vitamin C with a density of bone mass of gymnastics partisipants in Asia Mega Mas Housing at Sukaramai, Medan in 2013. This study was an observational with cross sectional study design. The number of subject was calculated using statistical formulas and samples were determined using purposive sampling technique with total of 67 people. Chi Square was applied and followed by a test of multivariate logistic regression to evaluate the most influence variable on bone mass density. The results showed that there were significant relationships for the three independent variables with bone mass density $(p<0.05)$. Logistic regression test found that the most affected factor to bone mass density of gymnastics participants was calcium. For the people who like sport and have aged $>30$ years, intake adequately of calcium should be considered to prevent bone loss (osteoporosis) prematurely.
\end{abstract}

Keywords: gymnastics habits, calcium, vitamin C, bone mass density

\section{ABSTRAK}

Osteoporosis pada perempuan di mulai pada usia 30 tahun dan meningkat secara nyata di usia 50 tahun, atau sekitar usia menopause dan prevalensi nya 80 persen terjadi pada kaum perempuan. Pencegahannya dengan melakukan olahraga dan memperhatikan asupan makanan tinggi kalsium, dan vitamin $\mathrm{C}$. Tujuan penelitian adalah mengetahui kebiasaan berolahraga senam, asupan kalsium dan vitamin $C$ dengan densitas massa tulang peserta senam di komplek Asia Mega Mas Sukaramai Medan tahun 2013. Penelitian ini bersifat observasional dengan desain penelitian cross sectional. Perhitungan sampel menggunakan rumus statistik didapatkan jumlah 67 orang orang. Penentuan sampel ditentukan melalui teknik purposive sampling. Analisis bivariat digunakan uji chi square, dilanjutkan uji logistik regresi multivariat untuk melihat variabel yang paling mempengaruhi densitas massa tulang. Hasil penelitian ini menunjukkan ada hubungan yang bermakna untuk ketiga variabel independent yang mempengaruhi densitas massa tulang $(p<0,05)$. Sedangkan uji lanjutan dengan uji logistik regresi didapatkan asupan kalsium yang paling mempengaruhi densitas massa tulang peserta senam. Bagi masyarakat yang suka berolahraga dan berusia $>30$ tahun sebaiknya kegiatan olahraga diikuti dengan asupan kalsium yang cukup untuk mencegah terjadi pengeroposan tulang (osteoporosis) yang lebih cepat.

Kata kunci: kebiasaan senam, kalsium, vitamin C, densitas massa tulang

\section{PENDAHULUAN}

emakin bertambah usia seseorang, maka akan terjadi sejumlah perubahan fisiologis yang tidak hanya mempengaruhi penampilan, tetapi juga fungsi tubuh dan respon kejiwaan terhadap masalah kehidupan sehari- hari. Fungsi tubuh mengalami penurunan akibat proses penuaan atau yang disebut penyakit degeneratif, seperti osteoporosis yang terjadi pada manusia menjelang lanjut usia. ${ }^{1}$

Osteoporosis saat ini menjadi salah satu penyebab penderitaan dan cacat yang paling sering pada orang berusia lanjut dan 80 persen 
terjadi pada kaum wanita. Namun, pengaruh zat gizi yang salah, obat-obatan, kebiasaan merokok, alkohol dan faktor-faktor lain menyebabkan osteoporosis juga bisa timbul pada orang muda dan kaum pria. $^{2}$

Osteoporosis adalah suatu keadaan yang ditandai dengan penurunan densitas yang cepat dan penipisan jaringan tulang sehingga mengakibatkan meningkatnya kerapuhan tulang dan risiko keretakan tulang. Jadi, osteoporosis ditandai oleh dua hal, yaitu pertama densitas (kepadatan) tulang berkurang, dan kedua kualitas tulang juga menurun. Densitas tulang bisa diukur dengan berbagai alat, sedangkan kualitas tulang tidak dapat dihitung dengan angka. ${ }^{3}$

Asupan kalsium dan aktivitas fisik memberikan hubungan positif kuat terhadap kepadatan tulang. Kalsium yang masuk ke tubuh tidak semuanya terserap, hanya sekitar 30-50 persen. Menurut perkiraan para ahli, simpanan kalsium dalam tubuh berkurang sekitar 1 persen setahun, termasuk ketika memasuki masa menopause pada wanita, yakni ketika memasuki usia 40-an di saat produksi hormon estrogen mulai berkurang. Kaum perempuan yang sudah mengalami menopause, bila tidak menjaga kesehatan tulang mereka, dalam waktu 5-7 tahun akan mengalami penurunan massa tulang sebanyak 25-30 persen. ${ }^{4,5}$

Prevalensi osteoporosis setiap tahun meningkat. Negara Amerika Serikat yang memiliki tingkat kemakmuran negara cukup tinggi, setiap tahunnya ada 1,5 juta orang yang menderita osteoporosis, terutama warga Amerika Serikat keturunan Afrika Amerika (Negro) mempunyai risiko di atas 10 persen mengalami osteoporosis dibandingkan ras Kaukasia. ${ }^{6}$ Sementara negara-negara di Asia, 52 persen perempuan di atas usia 50 tahun memiliki kepadatan tulang yang rendah. Jumlah penderita osteoporosis di Indonesia jauh lebih besar dari data terakhir Kementerian Kesehatan $\mathrm{RI}$, yaitu sebesar 19,7 persen dari seluruh penduduk. Catatan di beberapa kota seperti Jakarta, Surabaya, Semarang, Bandung dan Medan bahkan sudah mencapai 30 persen, lebih tinggi dari luar negeri. ${ }^{3}$

Penelitian lain di kota Jakarta, Bandung, Semarang, Surabaya, dan Medan tahun 2002 juga menunjukkan bahwa osteoporosis di
Indonesia sudah seharusnya diwaspadai. Dari 101.61 responden, ternyata 29 persen diantaranya telah menderita osteoporosis. ${ }^{3}$

Kehilangan tulang pada perempuan dapat terjadi pada usia 30 tahun dan meningkat secara nyata di usia 50 tahun, tepatnya sekitar usia menopause. Hal ini sesuai dengan hasil penelitian yang dilaksanakan oleh Kolowicz, yang menyatakan bahwa kejadian osteoporosis pada wanita lebih tinggi dibandingkan dengan pria. 7,8

Kalsium adalah mineral yang sangat penting untuk meningkatkan peak bone mass, artinya asupan kalsium yang tinggi dapat mencegah atau mengurangi kehilangan massa tulang pada perempuan pascamenopause. ${ }^{9}$ Penyerapan kalsium di dalam tubuh dapat dibantu oleh asupan vitamin C dalam memaksimalkan penyerapan kalsium di dalam tubuh sehingga keutuhan jaringan tulang tetap terpelihara dan akan memperkokoh tulang. Sumber vitamin C sebaiknya diperoleh dari bahan makanan yang alami seperti sayur dan buah-buahan. ${ }^{10}$

Penyerapan kalsium yang baik apabila dibarengi dengan aktivitas fisik berupa olahraga yang rutin, maka kepadatan tulang akan semakin baik karena kebiasaan olahraga dapat membantu memaksimalkan penyerapan kalsium untuk memadatkan tulang. Hal ini dibuktikan dengan olahraga secara teratur sejak usia remaja, memicu kesehatan tulang karena tarikan gaya berat dan berat badan pada tulang memelihara keutuhan jaringan tulang. ${ }^{1,11}$

Olahraga yang dimaksud untuk usia 30 tahun sebaiknya olahraga yang bersifat ringan dan tidak memerlukan waktu relatif lama, seperti olahraga senam aerobic yang dilakukan secara mandiri ataupun dikoordinir seperti kelompok senam pada komplek Asia Mega Mas. Hasil observasi peneliti pada tanggal 29 Mei dan 10 Juni 2013 kegiatan senam ini rutin dilakukan secara rutin setiap hari kecuali hari minggu, jumlah peserta yang mengikuti senam secara rutin berjumlah 210 orang, dimana peserta yang mengikuti senam kebanyakan wanita dengan usia berkisar di atas 30 tahun. Berdasarkan uraian di atas, penelitian ini bertujuan melihat hubungan kebiasaan berolahraga senam, asupan kalsium dan vitamin $\mathrm{C}$ dengan densitas massa tulang pada peserta senam di Komplek Asia Mega Mas Medan. 


\section{METODE PENELITIAN}

Penelitian ini merupakan observasional dengan rancangan cross sectional. Populasi adalah peserta senam dikomplek Asia Mega Mas Sukaramai Kota Medan yang berjumlah 210 orang, kemudian ditentukan pengambilan sampel dengan memakai rumus statistik dan didapatkan sampel minimal 67 orang. Teknik pengambilan sampel adalah teknik purposive sampling, dengan membuat kriteria inklusi meliputi; peserta tetap senam yang dibuktikan dari kartu anggota, berumur $\geq 30-56$ tahun, tidak dalam keadaan sakit, Sudah menjadi peserta senam $\geq 6$ bulan.

\section{Pengumpulan Data}

Pengumpulan data dilakukan dengan menggunakan kuesioner yang sudah dilakukan pengujian lapangan dan terstruktur. Peneliti dibantu oleh 6 orang enumerator yang berasal dari mahasiswa Jurusan Gizi.

\section{Pengolahan Data}

Data yang sudah dikumpulkan melalui form pengumpulan data, kemudian diolah secara manual selanjutnya dilakukan koding dan editing data.

Pemeriksaan densitas massa tulang dilakukan dengan memakai alat densitometer USG Portable GE-Logic 50 yang diproduksi oleh Kanada tahun 2011. Densitas massa tulang dilakukan dengan memeriksa bone mineral density (BMD) pada peserta senam dan skala pengukurannya $\mathrm{g} / \mathrm{cm}^{2}$ dengan menggunakan perhitungan T-Score. Rumus penghitungan T-Score adalah hasil dari BMD pasien dikurangi BMD rata-rata orang muda normal dibagi dengan standar deviasi rata-rata orang muda normal. Dari hasil perhitungan tersebut, kepadatan tulang kemudian dapat dibedakan menjadi dua kategori yaitu : T-Score normal, bila $>=-1,0$, dan T-Score rendah, bila $<-1,0$.

Data kebiasaan berolahraga senam dikumpulkan dengan metode wawancara dengan alat bantu kuesioner, kemudian dikategorikan menjadi 2, yaitu: baik 39-51 dari total skor dan kurang $\leq 38$ dari total skor.

Data asupan zat gizi (asupan kalsium dan vitamin C) diolah dengan bantuan program Nutrisurvey. Asupan kalsium dapat dikategorikan menjadi dua yaitu: normal $\geq 1000$ $\mathrm{mg}$, kurang $<1000 \mathrm{mg}$. Sedangkan asupan vitamin $C$ dapat dikategorikan menjadi dua yaitu: normal $70 \mathrm{mg}$ atau lebih, dan kurang $<70$ $\mathrm{mg}$.

\section{Analisis Data}

Data yang diolah kemudian dianalisis ke dalam distribusi frekuensi. Analisis univariat untuk menggambarkan masing-masing variabel yang disajikan dalam distribusi frekuensi dan dianalisis berdasarkan persentase.Analisis bivariat untuk melihat hubungan kebiasaan berolahraga senam dengan status kepadatan tulang, hubungan asupan kalsium dengan status kepadatan tulang dan hubungan asupan vitamin C dengan status kepadatan tulang. Dilakukan dengan uji korelasi Chi Square. Dengan mengambil kesimpulan, jika $p<0,05$ maka Ho ditolak dan jika $p>0,05$ maka $\mathrm{Ho}$ diterima. Analisis lanjutan dilakukan dengan uji logistic multivariat, untuk mengetahui variabel mana yang palinng mempengaruhi.

\section{HASIL}

\section{Karakteristik Peserta Senam}

Peserta senam sebagai sampel dalam penelitian ini sebagian besar berjenis kelamin laki-laki sebesar 61 persen sedangkan menurut umur variasi terbanyak ada pada kelompok 30 39 tahun sebesar 39 persen. Distribusi Karakteristik peserta senam dapat dilihat pada Tabel 1.

\section{Kebiasaan Berolahraga Senam, Asupan Kalsium, Asupan Vitamin C dan Dentitas Massa Tulang}

Kebiasaan olahraga dibutuhkan untuk mempertahankan kesehatan tulang. Kebiasaan berolahraga seperti melakukan senam 5 kali dalam seminggu mempengaruhi tulang secara langsung maupun tidak langsung. Kebiasaan berolahraga akan berpengaruh secara maksimal terhadap densitas massa tulang bila diikuti dengan asupan zat gizi yang adekuat terutama asupan kalsium dan vitamin $\mathrm{C}$ yang dapat memaksimalkan pembentukan (peak bone mass) terutama pada anak-anak dan remaja yang secara otomatis, akan membantu meningkatkan densitas tulang. . $^{1,12}$

Kebiasaan berolahraga senam yang dilaksanakan dengan baik oleh peserta senam 
sebesar 73,1 persen. Asupan kalsium yang diperlukan bagi pertumbuhan tulang, dikonsumsi peserta senam dengan kategori baik sebesar 76,1 persen sedangkan asupan vitamin $C$ peserta senam dengan kategori baik sebesar 76,1 persen.

Pada pemeriksaan densitas tulang didapati sebagian besar peserta senam masih dalam kategori normal sebesar 52,2 persen. Distribusi kebiasaan berolahraga senam, asupan kalsium, asupan vitamin $C$ dan dentitas massa tulang dapat dilihat pada Tabel 2.

\section{Hubungan Kebiasaan Berolahraga Senam, Asupan Kalsium, Asupan Vitamin C dengan Dentitas Massa Tulang}

Olahraga senam disebut juga dengan olahraga aerobik memiliki pengaruh positif terhadap kesehatan tulang. Orang dewasa dianjurkan melakukan kegiatan ini sedikitnya 30 menit selama 5 hari dalam seminggu dengan intensitas sedang. 2,13

Kepadatan tulang akan semakin baik bila diikuti dengan asupan kalsium sebesar 1000 $\mathrm{mg} / \mathrm{hari}$ terutama pada usia 19-50 tahun. Penyerapan kalsium akan menjadi maksimal bila dikonsumsi bersamaan dengan vitamin $\mathrm{C}$ yang diperoleh dari bahan makanan segar seperti sayur-sayuran dan buah-buahan. ${ }^{14}$

Tabel 1

Karakteristik Sampel Berdasarkan Jenis Kelamin dan Umur

\begin{tabular}{llcc}
\hline \multirow{2}{*}{ Karakteristik sampel } & Kategori & \multicolumn{2}{c}{ Frekuensi } \\
\cline { 3 - 4 } Jenis Kelamin & Laki-laki & 41 & 61 \\
& Perempuan & 26 & 39 \\
\multirow{3}{*}{ Umur (tahun) } & $30-39$ & 26 & 39 \\
& $40-49$ & 24 & 36 \\
& $\geq 50$ & 17 & 25 \\
\hline Jumlah & & 67 & 100 \\
\hline
\end{tabular}

Tabel 2

Distribusi Kebiasaan Berolahraga Senam, Asupan Kalsium, Asupan Vitamin C dan Dentitas Massa Tulang

\begin{tabular}{llcc}
\hline \multirow{2}{*}{ Variabel } & \multirow{2}{*}{ Kategori } & \multicolumn{2}{c}{ Frekuensi } \\
\cline { 3 - 4 } & & $\mathrm{n}$ & $\%$ \\
\hline Kebiasaan berolahraga senam & Kurang & 18 & 26,9 \\
Asupan kalsium & Baik & 49 & 73,1 \\
& Kurang & 16 & 23,9 \\
Asupan vitamin C & Baik & 51 & 76,1 \\
& Kurang & 16 & 23,9 \\
Densitas Massa Tulang & Baik & 51 & 76,1 \\
& Rendah & 32 & 47,8 \\
Jumlah & Normal & 35 & 52,2 \\
\hline
\end{tabular}


Tabel 3

Hasil Analisis Bivariat Antara Kebiasaan Senam, Asupan Kalsium Tulang dan Asupan Vitamin C dengan Densitas Massa Tulang

\begin{tabular}{lcc}
\hline Variabel & $\mathrm{n}$ & Nilai $\mathrm{p}$ \\
\hline Kebiasaan berolahraga senam dengan dentitas massa tulang & 67 & 0,001 \\
Asupan kalsium dengan densitas massa tulang & 67 & 0,001 \\
Asupan vitamin C dengan densitas massa tulang & 67 & 0,005 \\
\hline
\end{tabular}

Tabel 4

Hasil Uji Multivariat Kebiasaan Berolahraga Senam, Asupan Kalsium dan Asupan Vitamin C dengan Densitas Massa Tulang

\begin{tabular}{lllllll}
\hline Determinan & B & SE & Wald & Df & P & Exp \\
\hline Kebiasaan berolahraga senam & 1,7 & 0,77 & 5,25 & 1 & 0,022 & 5,87 \\
Asupan kalsium & 1,9 & 0,87 & 5,11 & 1 & 0,024 & 7,27 \\
Asupan vitamin C & 1,6 & 0,78 & 4,57 & 1 & 0,032 & 5,34 \\
\hline
\end{tabular}

Tabel 3 menunjukkan hasil uji bivariat untuk ketiga variabel independen terhadap densitas massa tulang dengan uji statistik chi-square, menunjukkan adanya hubungan bermakna secara signifikan dimana ketiga variabelnya signifikan.

\section{Faktor-Faktor yang Mempengaruhi Densitas Massa Tulang Peserta Senam}

Tabel 4 uji multivariat regresi logistik menunjukkan bahwa asupan kalsium memiliki pengaruh terhadap densitas massa tulang, dibandingkan kebiasaan berolahraga senam dan asupan vitamin C. Bila asupan kalsiumnya baik akan mempengaruhi densitas massa tulang menjadi lebih baik juga sebesar 7,27 dibandingkan dengan peserta senam yang mempunyai densitas massa tulang yang rendah. Study epidemiologis yang telah banyak dilakukan menunjukkan bahwa konsumsi kalsium memiliki keterkaitan yang cukup konsisten dengan kepadatan tulang ${ }^{12,15}$

\section{BAHASAN}

Kebiasaan berolahraga sebaiknya dilakukan secara teratur dimulai sejak anakanak hingga dewasa. Kegiatan olahraga akan membantu pembentukan massa tulang lebih tinggi dibandingkan orang yang tidak melakukan kegiatan olahraga. Jenis olahraga yang membantu pembentukan densitas massa tulang adalah olahraga yang bekerja melawan gravitasi seperti jogging, menari, senam.2,16 Kegiatan senam yang dilakukan dikomplek Asia Mega Mas Sukaramai sudah menjadi kebiasaan penduduk sekitar komplek, hampir 90 persen peserta yang menjadi anggota melakukan kebiasaan senam minimal tiga kali dalam seminggu, hal ini disebabkan karena kegiatan senam ini selain menyehatkan, tidak memerlukan durasi waktu yang lama, lokasi dekat dari perumahan serta kegiatan senam ini dijadikan ajang silahturahmi penduduk setempat. Asupan zat gizi yang adekuat dapat membantu perkembangan massa tulang terutama zat gizi yang mempunyai peranan penting dalam pembentukan tulang seperti kalsium dan vitamin $\mathrm{C}$.

\section{a. Asupan kalsium}

Untuk memenuhi kebutuhan kalsium, tubuh mengambilnya dari makanan yang dimakan atau dari tulang, karena kebanyakan mineral dan vitamin memang tidak dapat diproduksi sendiri oleh tubuh. ${ }^{17}$ Kalsium dapat ditemukan baik dari makanan nabati maupun hewani. Contoh bahan makanan sumber kalsium nabati yang sering dikonsumsi adalah: sayuran hijau, kacang- 
kacangan, susu kedele (air tahu) dan bijibijian. Sayuran hijau yang kaya akan kalsium antara lain adalah bayam, sawi, daun pepaya, daun singkong, daun kacang panjang. Sedangkan sumber makanan hewani contohnya adalah: susu dan ikan yang dimakan bersama tulangnya termasuk ikan teri, udang kering, ikan sarden dalam kaleng, makarel, ikan salmon. Sumber bahan makanan kalsium ini selalu dikonsumsi oleh peserta senam, sehingga asupan kalsiumnya termasuk kategori tinggi. ${ }^{18}$

b. Asupan vitamin $C$

Vitamin C pada umumnya hanya terdapat di dalam pangan nabati, yaitu sayuran daun-daunan dan jenis kol juga pada buah terutama yang asam, seperti jeruk, nanas, rambutan, pepaya, dan tomat. ${ }^{17} \mathrm{Hal}$ ini dapat dilihat pada menu yang dikomsumsi peserta senam dengan melakukan recall makanan selama 3 hari tidak berturut-turut yakni sampel sering mengonsumsi sayuran hijau dan buahbuahan seperti sawi, pepaya, jeruk, tomat dan mangga yang kaya kandungan vitamin C. Bahkan para peserta senam memulai aktifitas pagi dengan mengonsumsi segelas jus sebelum melakukan senam.

\section{Hubungan Kebiasaan Berolahraga Senam Dengan Densitas Massa Tulang Peserta Senam}

Dari hasil uji statistik menggunakan ChiSquare diperoleh nilai $p=0.001<0.05$ artinya ada hubungan yang bermakna antara kebiasaan berolahraga senam dengan densitas massa tulang. Hasil ini didukung oleh jawaban pada pertanyaan yang menyatakan bahwa melakukan olahraga senam $\geq 3$ kali seminggu sebanyak 40 orang (59.7\%) kemudian peserta senam yang melakukan olahraga di atas 15 menit sebanyak 38 orang $(56.7 \%)$ dan waktu senam yang dilakukan pada pagi hari sebanyak 67 orang (100\%). Kegiatan olahraga tersebut dilakukan pada pagi hari di lapangan terbuka dimana sinar matahari yang mengandung vitamin $D$ akan diserap sehingga mempengaruhi terjadinya mineralisasi kalsium berjalan dengan maksimal. Dengan kebiasaan berolahraga yang seperti ini maka peserta senam memiliki densitas massa tulang yang baik. ${ }^{2} \mathrm{Hal}$ ini sesuai dengan pernyataan bahwa olahraga secara teratur sejak usia remaja memicu kesehatan tulang, karena tarikan gaya berat dan berat badan pada tulang memelihara keutuhan jaringan tulang, apalagi kegiatan olahraga tersebut dilakukan dilapangan terbuka yang banyak terkena paparan sinar matahari. ${ }^{1,2}$

Olahraga yang melibatkan sebagian otot tubuh, latihan kontraksi otot yang dinamis maupun statis dilakukan diluar ruang/alam terbuka (cukup sinar matahari) latihan terbebani berat badan dan gravitasi.2,19 Olahraga yang terbebani berat badan dan membuat tubuh melawan gravitasi yaitu gerak jalan, jogging, senam, menari, naik turun tangga dll. Olahraga tersebut dilakukan untuk meningkatkan sirkulasi darah pada tulang dengan meningkatkan hormon testoteron dan estrogen yang penting dalam memelihara tulang serta meningkatkan kolagen dan garam mineral di dalam matriks tulang dan membuat tulang menjadi lebih kuat. ${ }^{20}$

\section{Hubungan Asupan Kalsium Dengan Densitas Massa Tulang Peserta Senam}

Dari hasil uji statistik menggunakan ChiSquare diperoleh nilai $p=0.001<0.05$ artinya ada hubungan yang bermakna antara asupan kalsium dengan densitas massa tulang peserta senam.

Asupan kalsium sesuai kebutuhan harus terus diberikan dan dipertahankan agar proses pembentukan tulang kembali berjalan dengan stabil, sehingga terbentuklah tulang yang sehat, padat, dan kuat dengan itu maka reabsorpsi kalsium dari tulang berjalan lambat atau tidak sama sekali.3,12. Hal ini juga diperkuat dengan hasil penelitian terhadap 36.262 wanita menopause oleh Women's Health Institute di Amerika Serikat ditemukan bahwa $1000 \mathrm{mg}$ kalsium ditambah 400 IU vitamin D setiap hari terbukti efektif mengurangi kejadian fraktur tulang panggul serta mengurangi rasa nyeri pada tulang. 2,21

Bagi orang dewasa, peran kalsium makanan adalah untuk mencegah kerapuhan tulang yang dapat diperoleh dari asupan kalsium dengan mengkonsumsi 3-4 cangkir susu atau 2-3 cangkir yoghurt setiap hari. Kalsium bergabung dengan mineral lain membentuk kristal padat yang akan memberikan kekuatan pada tulang. Apabila 
pasokan kalsium kurang, beberapa kristal ini larut dan memberikan kalsium ke darah. Pernyataan ini didukung oleh beberapa penelitian yang dilakukan di negara-negara yang mengkonsumsi susu lebih banyak jarang mengalami patah tulang, tetapi masyarakat di negara yang tidak banyak mengkonsumsi susu atau produk olahannya cenderung mengalami patah tulang. 3,22

Hal ini sejalan dengan penelitian yang dilakukan Marjan (2013) yang menyatakan bahwa kecukupan asupan kalsium sangat penting untuk mencapai massa tulang puncak optimal dan mengurangi laju kehilangan tulang karena bertambahnya usia. Tingkat kecukupan kalsium pada subjek yang mengalami osteoporosis sebagian besar berada pada kategori defisit $(75,9 \%)$, sedangkan pada subjek yang tidak osteoporosis sebagian besar berada pada kategori normal $(75,0 \%){ }^{4}$

\section{Hubungan Asupan Vitamin C Dengan Densitas Massa Tulang Peserta Senam}

Dari hasil uji statistik menggunakan ChiSquare diperoleh nilai $p=0.005<0.05$ artinya ada hubungan yang bermakna antara asupan vitamin $\mathrm{C}$ dengan densitas massa tulang peserta senam.

Kekurangan vitamin C selain dapat menimbulkan penyakit scurvy, juga dapat mengurangi pembentukan tulang dan meningkatkan pengeroposan tulang. ${ }^{23} \mathrm{Hal}$ ini dikarenakan asupan vitamin C membantu memaksimalkan penyerapan kalsium di dalam tubuh sehingga keutuhan jaringan tulang tetap terpelihara, selain vitamin $C$ juga bertindak membantu proses pembetukan kolagen, dimana fungsinya untuk memperkokoh tulang. ${ }^{9,10}$ Juga membantu pembentukan matriks tulang terutama tulang rawan. ${ }^{17}$

Bila dilihat dari jenis sumber vitamin $\mathrm{C}$ yang dikonsumsi peserta senam yang kebanyakan berasal dari buah-buahan tetapi pengolahannya dilakukan dengan cara di jus dan mengkonsumsinya tidak langsung diminum pada saat selesai di blender, keadaan seperti ini akan mengurangi efektivitas dari vitamin $\mathrm{C}$. Hal ini disebabkan vitamin $\mathrm{C}$ akan berkurang kadarnya bila bersentuhan dengan udara dimana vitamin $C$ akan mengalami proses oksidasi. ${ }^{17}$
Hal ini sesuai dengan hasil penelitian dari Centre for Nutrition and Food Safety, Inggris, mendapati bahwa perempuan yang sering mengkonsumsi vitamin $\mathrm{C}$ dari buah dan sayur pada masa kanak-kanaknya akan memiliki tulang yang lebih padat daripada mereka yang kurang mengkonsumsi sayur dan buah. Sayuran hijau dan buah akan menjaga keseimbangan asam-basa tubuh dengan sifat basanya (alkali) sehingga kehilangan kalsium tubuh melalui air seni dapat dicegah. ${ }^{24}$

Penelitian yang dilakukan oleh Evans, 2008 menyatakan bahwa efek kekurangan vitamin $\mathrm{C}$ pada seorang atlet akan menyebabkan gangguan daripada pembentukan otot rangka tubuh, seorang atlet juga dapat menurunkan daya tahan tubuh. Sedangkan penelitian yang dilakukan oleh Macdonald, 2004 melaporkan bahwa vitamin C yang diperoleh dari buahbuahan dan sayur-sayuran membantu pembentukan kolagen hydrocylasi dan memberikan efek peningkatan bone mineral density (BMD) dan menurunkan kehilangan mineral tulang. ${ }^{9,10}$

\section{Hasil Uji Multivariat Secara Bersama Variabel Kebiasaan Berolahraga Senam, Asupan Kalsium dan Asupan Vitamin C dengan Densitas Massa Tulang.}

Untuk mendapatkan kesimpulan faktor yang paling berpengaruh terhadap densitas massa tulang dilakukan uji logistik regresi multivariat dan ditemukan asupan kalsium merupakan variabel yang paling berpengaruh (exponent value $=7,27$ ). Hal ini disebabkan peserta senam memperoleh asupan kalsium dari bahan makanan sumber nabati seperti air tahu (susu kedelai), tahu, kacang-kacangan, biji-bijian dan sayuran hijau. Sedangkan sumber kalsium dari hewani diperoleh dengan mengkonsumsi susu dan hasil olahannya, sebelum melakukan kegiatan senam di pagi hari. Untuk membantu penyerapan kalsium yang dikonsumsi peserta senam, vitamin D merupakan vitamin yang berpengaruh terhadap aliran kalsium dari saluran cerna ke pembuluh darah, selanjutnya menuju kebagian tulang. Vitamin $D$ diperoleh peserta senam dari matahari karena kegiatan senam yang dilakukan berlangsung di arena terbuka serta dilaksanakan pada pagi hari pukul 08.00-09.00 WIB setiap harinya. Pajanan matahari selama 
5-20 menit akan memperoleh vitamin $D$ yang cukup dimana vitamin $\mathrm{D}$ membantu proses mineralisasi tulang. 2,25

Hasil ini sejalan dengan penelitian Maspaitella, 2012 yang menyatakan bahwa kalsium merupakan mineral yang dibutuhkan dalam memaksimalkan (peak bone mass) terutama pada masa remaja sedangkan asupan kalsium pada orang dewasa diperuntukkan untuk menghindari terjadinya pengeroposan tulang. Anjuran konsumsi kalsium setiap harinya untuk usia > 30 tahun sebanyak $1000 \mathrm{mg}$ akan menghindari terjadinya osteoporosis. ${ }^{26}$ Penelitian yang dilakukan Anderson dalam Hardinsyah 2008 menyatakan faktor genetik dan umur juga menentukan sekitar 60 persen perkembangan massa tulang.

\section{SIMPULAN DAN SARAN}

\section{Simpulan}

Hasil penelitian menunjukkan adanya hubungan yang bermakna antara kebiasaan berolahraga senam, asupan kalsium dan asupan vitamin $\mathrm{C}$ terhadap densitas massa tulang. Sedangkan pada penelitian ini yang paling berpengaruh terhadap densitas massa tulang adalah asupan kalsium dimana semakin baik asupan kalsium maka semakin besar kemungkinan untuk tidak menderita osteoporosis (densitas massa tulangnya normal).

\section{Saran}

Bagi masyarakat yang suka berolahraga dan berusia $>30$ tahun sebaiknya kebiasaan kegiatan berolahraga dibarengi dengan asupan kalsium yang cukup untuk mencegah terjadi pengeroposan tulang (osteoporosis) yang lebih cepat.

\section{RUJUKAN}

1. Almatsier S, Soetardjo S, Soekatri M. Gizi Seimbang Dalam Daur Kehidupan. PT. Gramedia; 2011.

2. Stone, K.W. Program olahraga: Osteoporosis. Paduan Untuk Tulang yang Lebih Sehat. PT Citra Aji Parama;2009.

3. Tandra H. Segala Sesuatu yang Harus Anda Ketahui tentang Osteoporosis Mengenal, Mengatasi, dan Mencegah
Tulang Keropos. PT. Gramedia Pustaka Utama. Jakarta;2009

4. Marjan, A.Q. Marliyanti, S.A. Relationship Between Food Consumption and Physical Activity with Risk of Osteoporosis in Elderly at Nursing Home in Bogor. Jurnal Gizi dan Pangan. Bogor; 2013;8(2).

5. Lester ME, Urso, Evans RK, Pierce JR, Spiering $B A$, Maresh CM. Influence of exercise mode \& osteogenic index on bone biomarker responses during shortterm physical training. Bone. 2009;45-768776.

6. Miklus,T.R. Prevalence of Osteoporosis and Osteopenia among African Americans with Early Rheumatoid Arthritis: The Impact of Ethnic- Specific Normative Data. Journal of The National Medical Association USA; 2005 97(8):1155-1160.

7. Nieves, J. W. Osteoporosis: The Role of Micronutrients. The American of Clinical Nutrition. USA; 2005.

8. Lukman $M$ dan Juniarti N. Skrining Osteoporosis: Hubungan Usia Dan Jenis Kelamin Dengan Kejadian Osteoporosis di Desa Cijambu Kecamatan Tanjung Sari; Skrining Osteoporosis. 2009;10(19).

9. Evans J. W. Vitamin E, Vitamin C and Exercise. American Journal of Clinical Nutrition. USA; 2008; 72:647-52S.

10. Macdonald H. M. et al_Nutritional associations with bone loss during the monopausal transition : evidence of a beneficial effect of calcium, vitamin $\mathrm{C}$, alcohol, and fruit and vegetable nutrients and of a detrimental effect of fatty acids, The American Journal of Clinical Nutrition;2004

11. Beshgetoor D, Nichols JF, Rego I. Effect of training mode and calcium intake on bone mineral density in female master cyclist, runners, and non-athletes. Int J Sport Nutr Exerc Metab. 2000;10:290-301.

12. Maspaitella, M.L. Hubungan Asupan Kalsium dan Fospor, Indeks Massa Tubuh, Persen Lemak Tubuh, Kebiasaa Olahraga, Usia Awal Menstruasi dengan Kepadatan Tulang pada Remaja Putri. Journal of Nutrition. Semarang;2012. Vol 1. No 1.

13. Boot AM, Deridder MAJ, Pols HAP, Krenning EP, Keizer-Schrama SD. Bone Mineral Density In Children and Adolescents: Relation to puberty, Calcium 
Intake, and Phycisal Activity. Journal of Crinical Endocrinnology and Metabolism. 1997;87(1):57-62.

14. Spears J. W, William P. W. Role of antioxidants and trace elements in healhth and immunity of transition dairy cows. The veterinary Journal 2008:176:70-76.

15. Alghadir Ahmad H, Aly Farag A, Gabr Sami A. Effect of moderate aerobic training on bone metabolism indeces among adult humans. Pak $\mathrm{J}$ Med Sci 2014; 30 (4): 840-844.

16. Meikawati $W$ dan Amalia R.Hubungan Kebiasaan Minum Susu dan Olahraga Dengan Kepadatan Tulang Remaja (Studi Di SMAN 3 Semarang)._Prosiding Seminar Nasional UNIMUS. Semarang;2010

17. Almatsier, Sunita.Prinsip Dasar IImu Gizi. PT. Gramedia Pustaka Utama. Jakarta;2009

18. Yamborisut Uruwan, Wimonpeerapttana $W$, et al. Calcium Intake in Relation to Body Mass Index and Fatness in Thai School-Aged Children. Open Journal of Pediatrics. 2015;5:104-112.

19. Irwin ML et al. Effect of exercise on total and intra-abdominal body fat in postmenopausal women: a randomized controlled trial. JAMA. 2003;289(3):32330.

20. Beshgetoor D, Nichols JF, Rego I. Effect of training mode and calcium intake on bone mineral density in female master cyclist, runners, and non-athletes. Int J Sport Nutr Exerc Metab. 2000:10:290-301.

21. Kalkwarf H.J, Khoury J.C, and Lanphear B.P. Milk intake During Childhood And Adolescence, Adult Bone Density, And Osteoporotic Fractures In US Women. Am J Clin Nutr.2003;77:257-265.

22. Hardinsyah, Damayanthi E, dan Zulianti W. Hubungan Konsumsi Susu Dan Kalsium Dengan Densitas Tulang Dan Tinggi Badan Remaja. Jurnal Gizi dan Pangan. Bogor; Maret 2008.

23. Rosen C.J, Klibanski A. Bone, Fat, and Body Composition; Evoluing Conecepts in the Pathogenesis of Osteoporosis. The American Journal of Medicine. 2009;122:409-414.

24. Adriani M dan Wirjatma B. Peranan Gizi dalam Siklus Kehidupan. Kencana. Jakarta; 2012

25. Mc Tieman A et al. 2007. Exercise Effect on Weight and Body Fat in Men and Women. Obesity. 2007;15:1496-1512.

26. Bischoff F. H. A et al. Calcium Intake And Hip Fracture Risk In Men And Women: A Meta-Analysis of Prospective Cohort Studies And Randomized Controlled Trials. Am J Clin Nutr 2007;1780-90. 
